\title{
Uranium in the
}

East Walker River

Area, Lyon County

Nevada

GEOLOGICAL SURVEY BULLETIN 988 - C

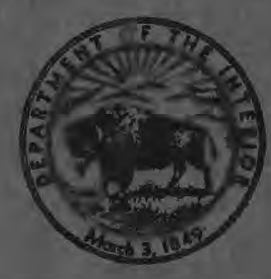





\section{Uranium in the}

East Walker River

Area, Lyon County

Nevada

By M. H. STAATZ and H. L. BAUER, Jr.

A CONTRIBUTION TO THE GEOLOGY OF URANIUM

GEOLOGICAL SUR VEY B ULLE T I N 988 -C

This report concerns work done on behalf of the U.S. Atomic Energy Commission and is published with the permission of the Commission

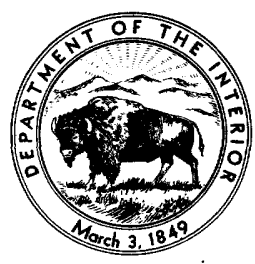




\title{
UNITED STATES DEPARTMENT OF THE INTERIOR
}

OSCAR L. CHAPMAN, Secretary

\author{
GEOLOGICAL SURVEY
}

W. E. Wrather, Director 


\section{CONTENTS}

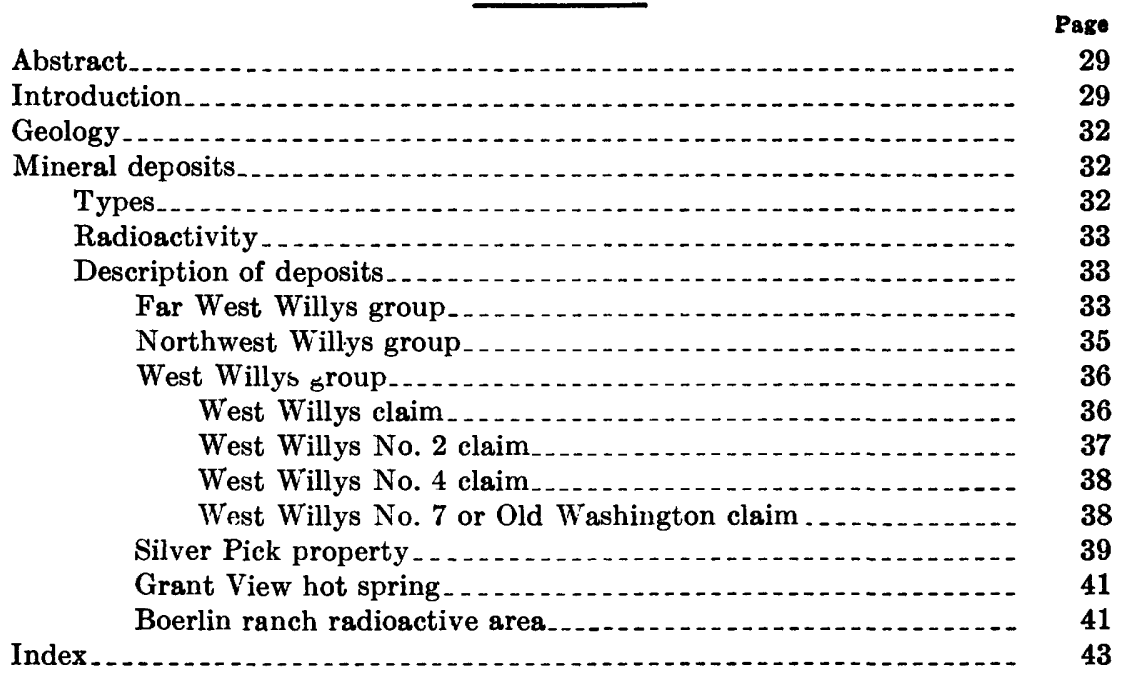

\section{ILLUSTRATIONS}

Prate 4. Geologic map and sections of the eastern part of the Far West Willys group of claims, Lyon County, Nev ...... In pocket

5. Geologic map and sections of the West Willys claim..... In pocket

6. Geologic map and sections of the West Willys No. 7 claim.... In pocket

7. Plans of the underground workings, West Willys No. 7 claim . . ........... In poeket

Fiaure 15. Index map showing East Walker River area........... 30

16. Plan and sketch of east wall of the new shaft, Silver Pick

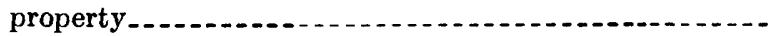





\title{
A CONTRIBUTION TO THE GEOLOGY OF URANIUM
}

\author{
Uranium in the East Walker River area, Lyon County, Nevada
}

\author{
By M. H. Staatz and H. L. Bader, Jr.
}

\section{ABSTRACT}

Craniferous quartz veins and uraniferous deposits of other types occur in an area at least 6 miles long and 3 miles wide, along the East Walker River in Lyon County, Nev. Most of the deposits are on the west side of the river.

Six properties or areas were mapped, sampled, and tested radiometrically. These properties are: the Far West Willys group, Northwest Willys group, West Willys group, Silver Pick property, Grant View hot spring, and the Boerlin ranch radioactive area.

The East Walker River area is underlain by coarse-grained porphyritic granite. Cutting the granite are numerous aplite dikes and a few perthitequartz pegmatites. Faults were seen in a few places.

Radioactive material was found in the East Walker River area in deposits of four types: (1) quartz veins carrying small amounts of copper, lead, and silver minerals ; (2) partly altered granite adjacent to quartz veins; (3) gouge zones; and (4) hot springs. The quartz vein deposits are the most abundant. The uranium minerals pitchblende and kasolite occur in the quartz veins, in aggregates and streaks associated with copper and silver minerals, galena, and barite. In many quartz veins abnormal radioactivity is absent or only locally present. Samples collected from quartz veins contain from 0.001 to 0.14 percent uranium; only 5 of 46 samples contain more than 0.025 percent uranium.

Partly altered granite adjacent to the quartz veins in the West Willys No. 7 property contains scattered torbernite, but the highest uranium content in deposits of this type is 0.006 percent.

The third type of deposit is represented on the Silver Pick property, where a gouge zone of differing thickness contains scattered flakes of torbernite. Five samples from this deposit contain from 0.005 to 0.013 percent uranium.

The Grant View hot spring is moderately radioactive near the point where it issues from the hillside. Laboratory analysis of both water and sand from this deposit shows little uranium content $(0.02 \mathrm{ppm})$ and little radioactivity, which indicates that the radioactivity is due to some short-lived daughter product, probably radon.

The uraniferous material found to date in the area is of too low grade and small size to be of value at present.

\section{INTRODUCTION}

Quartz veins and deposits of other types are uraniferous in an area at least 6 miles long and 3 miles wide in Lyon County, Nev. (fig. 15). The area trends north-northeast along the East Walker River, 


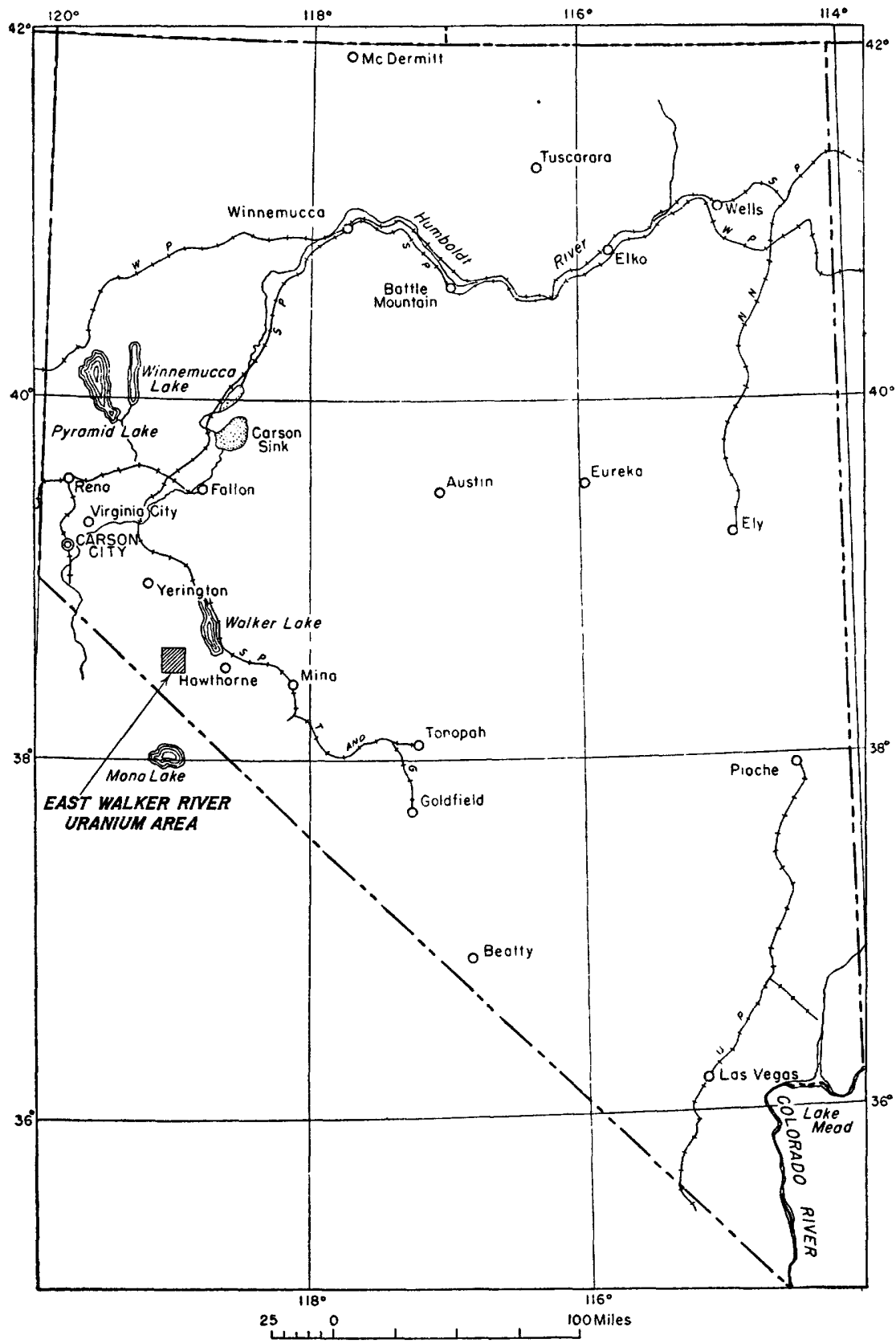

Fradna 15.-Index map showing East Walker River area. 
and most of the uranium occurrences are on the west side of the river. The area is in the Old Washington mining district, and its western edge is in the Mono division of the Toiyabe National Forest. The area is in secs. $28,29,32,33,34$, and 35, T. 8 N., R. 27 E., and secs. 3, 4, 5, 6, 7, 8, 9, 17, and 18, T. 7 N., R. 27 E., Mount Diablo meridian.

Several properties in the East Walker River area were mined for silver between 1880 and 1900. Past production from the area is not known but was probably small. Work on uranium has consisted only of prospecting.

The region is 5,100 to $6,400 \mathrm{ft}$ in altitude. The topography is rugged, and some slopes are as steep as $45^{\circ}$. The East Walker River has cut a steep $V$-shaped canyon through granite but at present is aggrading.

The central part of the area is reached from Yerington, Nev., over 11 miles of tarred road and 30 miles of dirt road. A road log from the Yerington post office to the West Willys group is given below:

0.0 Yerington post office. Go south on State Route 3.

11.0 Junction. Take road straight ahead. State Route 3 goes to right.

22.6 Junction. Go straight ahead.

29.3 East Walker River airstrip.

36.7 Junction. Turn right to Lewis ranch.

36.9 Junction. Keep to left. Road to right goes to McLaughlin ranch.

37.4 Junction. Go straight ahead. Road to right goes to Mr. Lewis' house.

37.8 Junction. Turn to the right.

38.0 Junction. Turn to the right.

38.3 Junction. Turn to the right.

39.2 Cabin. Follow road up river.

40.0 Cross river on bridge.

40.5 Old silver mill.

41.3 Junction. This is end of road except for vehicles with four-wheel drive. Road to left goes to Far West Willys and Northwest Willys groups. Road to right continues for about $100 \mathrm{yd}$ and stops about $100 \mathrm{yd}$ short of the West Willys claim.

The Silver Pick property can be reached by proceeding straight ahead at the junction at 38.0 miles and continuing for several miles. The property is on the west side of the road.

After a brief visit by C. C. Towle, Jr., and Thomas Anderson of the U. S. Atomic Energy Commission, the area was studied by M. H. Staatz and H. L. Bauer, Jr., from September 30 to October 30, 1950. All known uranium occurrences were mapped and sampled. These included the following properties and areas: Far West Willys group; Northwest Willys group, West Willys group, Silver Pick property, Grant View hot spring, and the Boerlin ranch radioactive area. Radiometric measurements were taken on all properties with a Geiger counter, with the beta shield open and the probe in contact with the 
material. Fifty channel samples, 11 grab samples, and 1 water sample were analyzed for radioactivity and uranium content.

\section{GEOLOGY}

The East Walker River area is underlain by porphyritic granite of unknown age. Cutting the granite are numerous aplite dikes and a few perthite-quartz pegmatites. Most of the aplite dikes occupy northeast-trending joints. Faults are present but are obvious only where aplite dikes are offset and where gouge zones are found. To the east of the East Walker River area, the granite is overlain by coalbearing shales and sandstones of Tertiary age.

\section{MINERAI, DEPOSITS}

\section{TYPES}

Radioactive material was found in deposits of four types:

1. Quartz veins contain most of the radioactive material in the area. Uranium occurs in minute scattered pitchblende grains and rarely in kasolite, a lead-uranium silicate, in association with copper, lead, and silver minerals. Where these minerals are lacking the quartz veins are not uraniferous.

2. Iron-stained fractured and partly argillized granite is locally abnormally radioactive near the quartz veins on level 3 of the West Willys No. 7 claim. This rock contains small scattered grains of torbernite, probably derived from pitchblende in neighboring quartz veins.

3. Torbernite is also scattered through gouge in a shear zone at the Silver Pick property and may have been derived from primary uranium minerals associated with the lead and silver minerals, which occur in lenses of quartz along this zone.

4. The Grant View hot spring, on the east side of the East Walker River, is radioactive. Water from this hot spring when allowed to stand decreases rapidly in radioactivity. Laboratory analysis showed a uranium content of only $0.02 \mathrm{ppm}$, and it is probable that the initial radioactivity of this water is due to one of the short-lived daughter products of uranium, probably radon.

To the east of the area, in sec. 36, T. 7 N., R. 27 E., Tertiary sediments containing coal beds overlie the granite. The coal is subbituminous, has a high-ash content (see following table), and is similar in appearance to cannel coal. It seems to be high in tars and resins and can be ignited with a match. Because many coals and lignites are uraniferous, the coal beds were tested at several places with a Geiger counter, and two channel samples were cut across the 4 - $\mathrm{ft}$ coal bed in the Lewis coal mine. No abnormal radic stivity was noted, and the two channel samples contained only 0.002 percent uranium in the ash. 
URANIUM, EAST WALKER RIVER AREA, LYON COUNTY, NEV.

Analyses of samples from the Lewis coal mine, Lyon County, Nev.

\begin{tabular}{l|r|r|r|r}
\hline Field no. & $\begin{array}{r}\text { Equivalent } \\
\text { uranium } \\
\text { (percent) }\end{array}$ & $\begin{array}{r}\text { Uranium } \\
\text { (percent) }\end{array}$ & $\begin{array}{r}\text { Ash } \\
\text { (percent) }\end{array}$ & $\begin{array}{r}\text { Uranium } \\
\text { in ash } \\
\text { (percent) }\end{array}$ \\
\hline $\begin{array}{r}\text { BS-1-50 } \\
\text { BS-2-50. }\end{array}$ & $\begin{array}{r}0.000 \\
.000\end{array}$ & $\begin{array}{r}0.001 \\
.002\end{array}$ & $\begin{array}{r}43.53 \\
42.03\end{array}$ & $\begin{array}{r}0.002 \\
.002\end{array}$ \\
\hline
\end{tabular}

\section{RADIOACTIVITY}

The quartz veins contain only local abnormal radioactivity. Of 46 samples, 41 contained 0.001 to 0.025 percent uranium, and only 5 contained 0.025 to 0.14 percent uranium. Of these 5 samples, 4 were of selected dump material. (See tables on pp. 35 and 37.)

Samples of altered granite contained 0.002 to 0.013 percent uranium.

Five samples of the gouge zone on the Silver Pick property contained 0.005 to 0.006 percent uranium.

Water from the Grant View hot spring contained $0.02 \mathrm{ppm}$ of uranium.

\section{DESCRIPTION OF DEPOSITS}

\section{FAR WEST WILLYS GROUP}

The Far West Willys group is about 1 mile west of the East Walker River, in secs. 5 and 6, T. 7 N., R. 27 E., and is reached from the West Willys group of claims by a steep, narrow dirt road, 2.5 miles long and passable only by jeep. The group consists of seven claims: the Far West Willys claim and the Far West Willys claims 2 to 7.

The Far West Willys group was located in 1949 and 1950 by Warren Loose, O. A. Kerlee, J. R. Ford, and L. O. Kerlee.

The area was prospected for silver between 1880 and 1900, and old workings include two shafts about $40 \mathrm{ft}$ deep, two tunnels $80 \mathrm{ft}$ and $125 \mathrm{ft}$ long, respectively, and numerous small pits and trenches, mostly caved. No silver was produced from the Far West Willys group. New workings consist of three bulldozer cuts and several small trenches.

The eastern two-thirds of the Far West Willys group, an area about $2,400 \mathrm{ft}$ long by $600 \mathrm{ft}$ wide, was mapped by plane table, and one old tunnel was mapped with Brunton compass and tape (pl. 4). The veins were tested radiometrically, and 16 samples were taken from 9 veins.

On the Far West Willys group of claims there are nine quartz veins more than 2 in. in width. The quartz veins are bounded by silicified and argillized granite, and commonly the extension of a vein beyond the point where it pinches out is marked by a silicified zone. Veins and silicified zones appear to follow small shears or faults in the granite, and slickensides are not uncommon. The nine quartz veins 
strike from N. $70^{\circ}$ E. to S. $75^{\circ}$ E. and dip from $60^{\circ}$ S. to $73^{\circ} \mathrm{N}$. Most of the silicified shear zones also have this trend. The strikes, dips, lengths, and average widths of the nine quartz veins are listed in the following table. Only veins 1,2 , and 3 are in the area covered by plate 4.

Vein dimensions, Far West Willys group

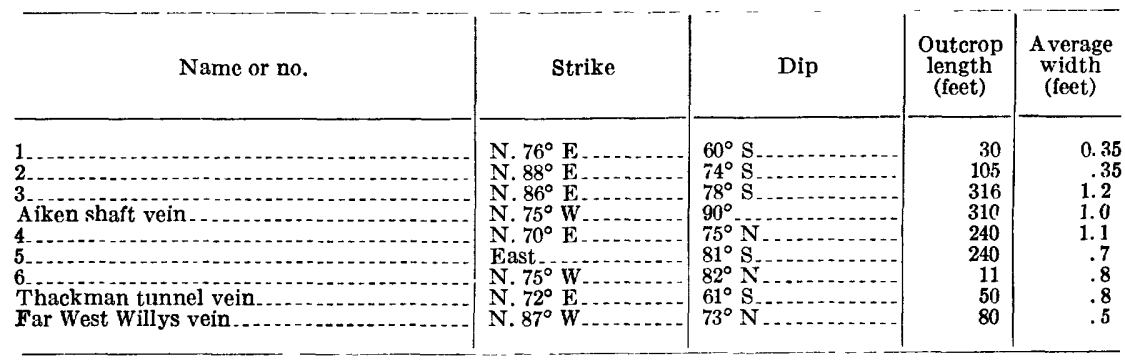

The Far West Willys group is underlain by a porphyritic granite consisting of about 7 percent euhedral orthoclase phenocrysts, 0.6 to 5 $\mathrm{cm}$ long, in a groundmass with an average grain size of $2.5 \mathrm{~mm}$. The groundmass consists of orthoclase (50 percent), quartz (21 percent), oligoclase (16 percent), microcline ( 9 percent), biotite (1.5 percent), spliene ( 1 percent), apatite ( 0.5 percent), magnetite ( 0.5 percent), and a trace of zircon and hornblende. The distinguishing features of this granite are the high sphene content and the orthoclase phenocrysts, which have hornblende inclusions oriented in a zonal pattern parallel to the prism faces of the orthoclase.

Numerous aplite dikes and a few pegmatites cut the granite. The aplite is an equigranular rock with a grain size of $0.5 \mathrm{~mm}$ and is estimated to consist of quartz (32 percent), orthoclase (26 percent), microcline (24 percent), oligoclase (18 percent), and a trace of biotite and magnetite. The aplite dikes are more common on the Far West Willys group of claims than in other parts of the district and range from a few feet to more than $500 \mathrm{ft}$ in length and from less than an inch to as much as $20 \mathrm{ft}$ in width. The few pegmatites in the area generally transect the aplite dikes as small stringers, but in the south-central part of the mapped area (pl. 4) two small pegmatites (38 and $62 \mathrm{ft}$ long) were found. The pegmatites have an average grain size of $1 \mathrm{in}$. and are estimated to consist of pink perthite (65 percent), quartz ( 35 percent), and traces of garnet and muscovite.

The veins consist chiefly of quartz, which commonly shows comb structure with well-developed crystals as much as an inch in diameter. Other minerals are irregularly distributed in thin layers and aggregates. Next in abundance to quartz is a yellowish-green mineral that coats cracks and fractures and is probably epidote. Copper, silver, and lead minerals are commonly found together and include chrysocolla, chalcopyrite, chalcocite, tenorite, galena, and argentite. Barite 
and calcite were each found in but one place. No uranium minerals were noted.

All veins were tested with a Geiger counter. Their radioactivity is only locally higher than average, and readings ranged from 2 to 20 divisions on the 0.2 scale of the counter. A small pile of rich silver ore just north of vein 1 gave a reading of 6 divisions on the 2.0 scale. Sixteen samples were taken from the nine veins. They contain from 0.002 to 0.14 percent uranium. (See following table.) The sample containing 0.14 percent uranium came from the selected ore pile north of vein 1. A grab sample from the dump of a pit on vein 5 contains 0.027 percent uranium. Only four veins yield material containing more than 0.010 percent uranium: vein 1, vein 5, Far West Willys vein, and a small vein less than 2 in. thick from a silicified zone (sample SJ-53-50).

Analyses of samples from Far West Willys group

\begin{tabular}{l|l|r|r|r}
\hline \multicolumn{1}{c|}{ Field no. } & Location & Description & $\begin{array}{c}\text { Equiva- } \\
\text { lent } \\
\text { uranium } \\
\text { (percent) }\end{array}$ \\
\hline Uranium \\
(percent)
\end{tabular}

\section{NORTHWEST WILLYS GROUP}

The Northwest Willys group is in sec. 29, T. 8 N., R. 27 E., and consists of the Northwest Willys and the Northwest Willys No. 1 claims. The claims were located in 1950 by Warren Loose, A. O. Kerlee, J. R. Ford, and L. O. Kerlee.

A radiometric traverse of the claims was made on October 15, 1950. Mine development consists of two short bulldozer cuts and two small prospect pits.

The country rock is a medium-grained porphyritic granite cut by aplite dikes. Two quartz veins having a general east-northeast trend and a steep dip cut the granite. The quartz vein on the Northwest Willys claim strikes $\mathrm{N}$. $55^{\circ} \mathrm{E}$. and dips $75^{\circ} \mathrm{NW}$. This vein has an average width of $1 \mathrm{ft}$ and is exposed on the surface for $250 \mathrm{ft}$. It grades into silicified granite on both ends. A pod of partly oxidized sulfides, $8 \mathrm{ft}$ long and $0.7 \mathrm{ft}$ wide, was seen in the vein near the loca- 
tion monument. This material, which contains galena, pyrite, chalcopyrite, copper oxides, limonite, and quartz, is the most radioactive material noted on the Northwest Willys claims. Readings ranged from 2 to 8 divisions on the 0.2 scale of a Geiger-Mueller counter. A $0.7-\mathrm{ft}$ channel sample (SJ-75-50) across the pod contains 0.003 percent uranium. Readings on the rest of the vein and on the granite ranged from 1 to 4 divisions on the 0.2 scale.

The vein on the Northwest Willys No. 1 claim strikes N. $85^{\circ}$ E. and dips $70^{\circ} \mathrm{SE}$. The vein averages $3 \mathrm{ft}$ in width and can be traced along the strike for $300 \mathrm{ft}$. It is composed of massive quartz, with a little green-copper stain at one place. Radiometric readings along the vein ranged from 1 to 5 divisions on the 0.2 scale. A 5.3-ft channel sample (SJ-76-50) across this vein contains 0.002 percent uranium.

\section{WEST WILLYS GROUP}

The West Willys group of claims is on both sides of an unnamed canyon $1 / 2$ mile to $1 \frac{1}{2}$ miles west of the East Walker River, in secs. 32 and 33, T. 8 N., R. 27 E. The group consists of seven claims: West Willys and West Willys Nos. 2, 3, 4, 5, 6, and 7. The claims were located in 1949 by Warren Loose, L. O. and O. A. Kerlee, and J. R. Ford. The West Willys No. 7 claim overlaps the Old Washington claim located by the Sierra Minerals Corp. A rough dirt road leads up the canyon within a few hundred yards of the claims. (See road log.) Four zones of closely spaced quartz veins have been found. The vein zones are on the West Willys, West Willys No. 2, West Willys No. 4, and the West Willys No. 7 claims. Plane-table maps were made of parts of the West Willys and West Willys No. 7 claims.

West Willys claim.-The West Willys claim is on the north side of the canyon, several hundred yards west of the end of the road. The area had previously been prospected and there are six old open-cuts (pl. 5). No recent work has been done. The property was mapped on a scale of $1 \mathrm{in}$. to $40 \mathrm{ft}$ by plane table, and 13 channel and grab samples were taken. Two quartz veins cut porphyritic granite similar to that on the Far West Willys claim. They lie in a zone that trends roughly N. $67^{\circ} \mathrm{W}$. (pl. 5). The eastern vein is exposed for $293 \mathrm{ft}$; it is 2 or $3 \mathrm{ft}$ thick in the central part and pinches down to $0.5 \mathrm{ft}$ at the west end. The western vein is $250 \mathrm{ft}$ long and ranges from 1 in. to $3 \mathrm{ft}$ in thickness. A zone of silicified granite as much as $11 / 2 \mathrm{ft}$ thick commonly borders the vein.

The veins consist almost entirely of gray to milky quartz with a few small drusy openings. The other minerals are in general sporadically distributed along the hanging-wall side of the vein. Sericite which forms fine veinlets through the quartz, is the chief accessory mineral. Chrysocolla, chalcocite, chalcopyrite, galena, and thin coatings of manganese oxides were noted. The radioactive material con- 
sists of a few grains of a dull-black mineral, probably pitchblende, which occurs in association with the copper and lead minerals, and thin coatings of an orange-yellow mineral that is associated with pitchblende(?) and copper and lead minerals in the central part of the western vein. The orange-yellow mineral has been identified as kasolite.

Radiometric testing indicated that the veins are mostly of average radioactivity. Locally readings were as high as 6 divisions on the 2.0 scale. Eight channel samples across the veins, three channel samples of the silicified granite bordering the footwall side of the western vein, and two grab samples were taken. (See following table.) The channel samples of the vein contain from 0.001 to 0.087 percent uranium. The three channel samples of the silicified granite contain only 0.002 percent uranium. Grab sample SJ-73-50 was taken from a pile of material from a sulfide-rich part of the eastern vein; grab sample SJ-74-50 came from the dump of a pit in the western vein and was selected by use of a counter. These samples contain 0.11 and 0.072 percent uranium, respectively.

Analyses of samples from West Willys claim

\begin{tabular}{|c|c|c|c|c|}
\hline Field no. & Location & Description & $\begin{array}{c}\text { Equiva- } \\
\text { lent ura- } \\
\text { niums } \\
\text { (percent) }\end{array}$ & $\begin{array}{l}\text { Uranium } \\
\text { (percent) }\end{array}$ \\
\hline $\begin{array}{l}\text { SJ } 63-50 \\
\text { SJJ64-50 } \\
\text { SJ-65-50 } \\
\text { SJ-66-50 } \\
\text { SJ-67-50 } \\
\text { SJ-68-50 } \\
\text { SJ } 699-50 \\
\text { SJJ-74-50 } \\
\text { SJJ-103-50 } \\
\text { SJ-70-50 } \\
\text { SJ } 71-50 \\
\text { SJ } 72-50 \\
\text { SJ-73-50 }\end{array}$ & 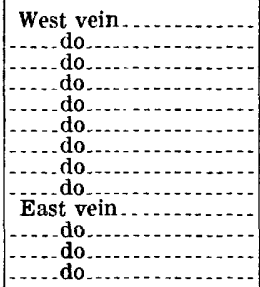 & $\begin{array}{l}\text { Quartz vein } \\
\text { Silicified granite-artz vein } \\
\text { Quarto do } \\
\text { Silicified granite-do } \\
\text { Dump (selected) } \\
\text { Quartz vein }\end{array}$ & $\begin{array}{l}0.093 \\
.002 \\
.018 \\
.001 \\
.013 \\
.002 \\
.002 \\
.063 \\
.001 \\
.001 \\
.003 \\
.008 \\
.100\end{array}$ & $\begin{array}{l}0.087 \\
.002 \\
.015 \\
.002 \\
.013 \\
.002 \\
.002 \\
.072 \\
.001 \\
.002 \\
.003 \\
.009 \\
.110\end{array}$ \\
\hline
\end{tabular}

West Willys No. 2 claim.-The West Willys No. 2 claim is near the top of a ridge about $450 \mathrm{ft}$ above and $1,500 \mathrm{ft}$ north of the main canyon. The shaft is about $500 \mathrm{ft}$ north of the workings at the western end of the West Willys No. 7 vein. Old workings consist of a shaft $30 \mathrm{ft}$ deep near the center of the vein and several small pits.

A quartz vein cutting porphyritic granite strikes N. $40^{\circ}-65^{\circ} \mathrm{E}$. and dips $75^{\circ} \mathrm{SW}$. The vein is exposed for $500 \mathrm{ft}$ along strike and ranges in width from less than 0.1 to $0.8 \mathrm{ft}$. The granite on either side of the vein is silicified. A little barite, galena, chrysocolla, chalcopyrite, and chalcocite were noted.

Radioactivity ranged from 1 to 5 divisions on the 0.2 scale of a Geiger-Mueller counter. A channel sample across the vein 
(SJ-85-50) contains 0.002 percent uranium. A selected sample from the dump (SJ-84-50) contains 0.022 percent uranium.

West Willys No. 4 claim.-The West Willys No. 4 vein is on the south side of the canyon, about $500 \mathrm{ft}$ southeast of the eastern vein on the West Willys claim. The old workings include a shaft 20 or $30 \mathrm{ft}$ deep, three open-cuts, and three small pits. A shear zone in porphyritic granite contains several branching quartz veins in echelon. The shear zone is $200 \mathrm{ft}$ long and trends N. $49^{\circ}$ E. The quartz veins dip from $56^{\circ} \mathrm{SE}$. to $90^{\circ}$. They pinch and swell and range in width from 0.1 to $0.9 \mathrm{ft}$, averaging about $0.6 \mathrm{ft}$.

The veins consist chiefly of white quartz, which locally is drusy. Chrysocolla, sericite, chalcocite, chalcopyrite, and galena occur in thin layers along the footwall or in scattered pods. The granite adjacent to the vein is argillized and silicified.

Radiometric readings on the barren quartz ranged from 1 to 5 divisions on the 0.2 scale of a Geiger counter. The parts of the veins containing the sulfides gave readings from 2 to 15 divisions on the 0.2 scale. Two channel samples that cut across the entire vein (SJ-77-50 and SJ-78-50) contain 0.003 percent uranium.

West Willys No. 7 or Old Washington claim.-The West Willys No. 7 or Old Washington claim is $900 \mathrm{ft}$ north of the main canyon and about $1500 \mathrm{ft}$ southeast of the West Willys claim. It is on a steep mountain face with a difference in altitude of about $300 \mathrm{ft}$ from the lower to the upper workings.

Between 1880 and 1900 this property was mined for silver and was called at that time the Old Washington mine. The production is un. known. The old workings include seven adits and three small opencuts. For this report the adits are numbered from the lowest upward (pls. 6 and 7). All adits are accessible, except No. 2. The adits range from 31 to $367 \mathrm{ft}$ in length. The vein was partly stoped out between levels 4 and 5. Below level 4 the veins continue, but the silver content is reported to have decreased below minable grade.

Narrow shear zones cutting granite contain quartz veins in echelon and irregular gouge zones. The shear zone exposed on the surface strikes $\mathrm{N}$. $77^{\circ} \mathrm{W}$. and consists of a series of slips having an average dip of $80^{\circ} \mathrm{S}$. It is exposed for more than $500 \mathrm{ft}$ along the strike. Another shear zone striking N. $51^{\circ}$ E. and dipping $73^{\circ} \mathrm{NW}$. is seen in the workings (pl. 6, section $A-A^{\prime} ;$ pl. 7 , level 3 ) but is not exposed at the surface. The junction of these two zones plunges about $38^{\circ}$ in a direction of S. $76^{\circ} \mathrm{W}$. Several small east-trending silicified zones crop out. The two major shear zones contain one or more quartz veins, which range from less than an inch to $1.5 \mathrm{ft}$ in thickness. Small cross faults striking N. $38^{\circ}$ E. to N. $25^{\circ} \mathrm{W}$. and dipping $50^{\circ}-60^{\circ} \mathrm{W}$. cut the veins and in some places offset them a few feet. The shear 
zones and quartz veins commonly are bordered by as much as $6 \mathrm{ft}$ of silicified and argillized granite.

The veins are almost entirely quartz. Pockets and streaks consisting of epidote, chrysocolla, barite, chalcopyrite, galena, chalcocite, and probably argentite occur sporadically along the vein. Specks of a dull-black highly radioactive mineral, probably pitchblende, were found in a pocket of sulfide minerals on level 4. At the face of level 3 , fine crystals of torbernite were found in altered granite adjacent to a quartz vein.

Locally, abnormal radioactivity was noted. Analyses of 17 channel and grab samples from this property range from 0.002 to 0.018 percent uranium. (See following table.) Only two of the samples (SJ-89-50 and SJ-90-50) contain more than 0.01 percent uranium; these were selected from material rich in sulfides mined from a stope on level 4.

Analyses of samples from West Willys No. 7 or Old Washington claim

\begin{tabular}{|c|c|c|c|c|}
\hline Field no. & Location & Description & $\begin{array}{c}\text { Equiva- } \\
\text { lent } \\
\text { uranium } \\
\text { (percent) }\end{array}$ & $\begin{array}{l}\text { Uranium } \\
\text { (percent) }\end{array}$ \\
\hline $\begin{array}{l}\text { SJ-94-50 } \\
\text { SJ }-95-50 \\
\text { SJ }-96-50 \\
\text { SJ }-97-50 \\
\text { SJ } 79-50 \\
\text { SJJ-80-50 } \\
\text { SJ }-81-50 \\
\text { SJ }-82-50 \\
\text { SJ }-83-50 \\
\text { SJ }-90-50 \\
\text { SJ }-91-50 \\
\text { SJJ } 92-50 \\
\text { SJ }-86-50 \\
\text { SJ }-87-50 \\
\text { SJ }-88-50 \\
\text { SJ }-89-50 \\
\text { SJ }-93-50\end{array}$ & 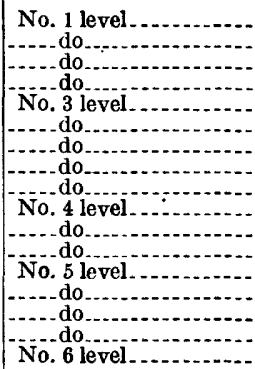 & $\begin{array}{l}\text { Argillized granite } \\
\text { Quartz vein } \\
\text { Brecciated quartz. } \\
\text { Argillized granite. } \\
\text { Quartz vein } \\
\text { do do } \\
\begin{array}{l}\text { Stoped rock (selected) } \\
\text { Quartz vein }\end{array} \\
\text { do do } \\
\begin{array}{l}\text { Stoped rock (selected) } \\
\text { Quartz vein }\end{array}\end{array}$ & $\begin{array}{l}0.004 \\
.001 \\
.003 \\
.006 \\
.007 \\
.008 \\
.011 \\
.004 \\
.003 \\
.014 \\
.002 \\
.003 \\
.006 \\
.001 \\
.002 \\
.014 \\
.002\end{array}$ & $\begin{array}{l}0.004 \\
.002 \\
.002 \\
.004 \\
.006 \\
.008 \\
.008 \\
.003 \\
.002 \\
.018 \\
.002 \\
.003 \\
.007 \\
.002 \\
.002 \\
.017 \\
.002\end{array}$ \\
\hline
\end{tabular}

\section{SILVFR PICK PROPFRTY}

The Silver Pick property is on the east side of a low ridge just west of the county road from the East Walker ranch to Aurora, in sec. 35 , T. 8 N., R. 27 E. The property was located 10 or $15 \mathrm{yr}$ ago for silver; uranium minerals were discovered in the spring of 1950 during assessment work. The property is owned by $\mathbf{L}$. W. Osborn and Art Baseman, of Yerington, Nev.

The old workings consist of an open-cut $17 \mathrm{ft}$ long and $10 \mathrm{ft}$ wide, a 16-ft adit at one end of the open-cut, a shaft $30 \mathrm{ft}$ deep, and several small pits. Since the discovery of uranium minerals a $34-\mathrm{ft}$ shaft was sunk along a shear zone at a 52-degree incline, and from the bottom of the shaft a tunnel $37 \mathrm{ft}$ long was driven (fig. 16).

A shear zone cutting granite strikes N. $30^{\circ}$ E. and dips $50^{\circ} \mathrm{NW}$. and can be traced from the new shaft for at least $210 \mathrm{ft}$ to the southwest. 


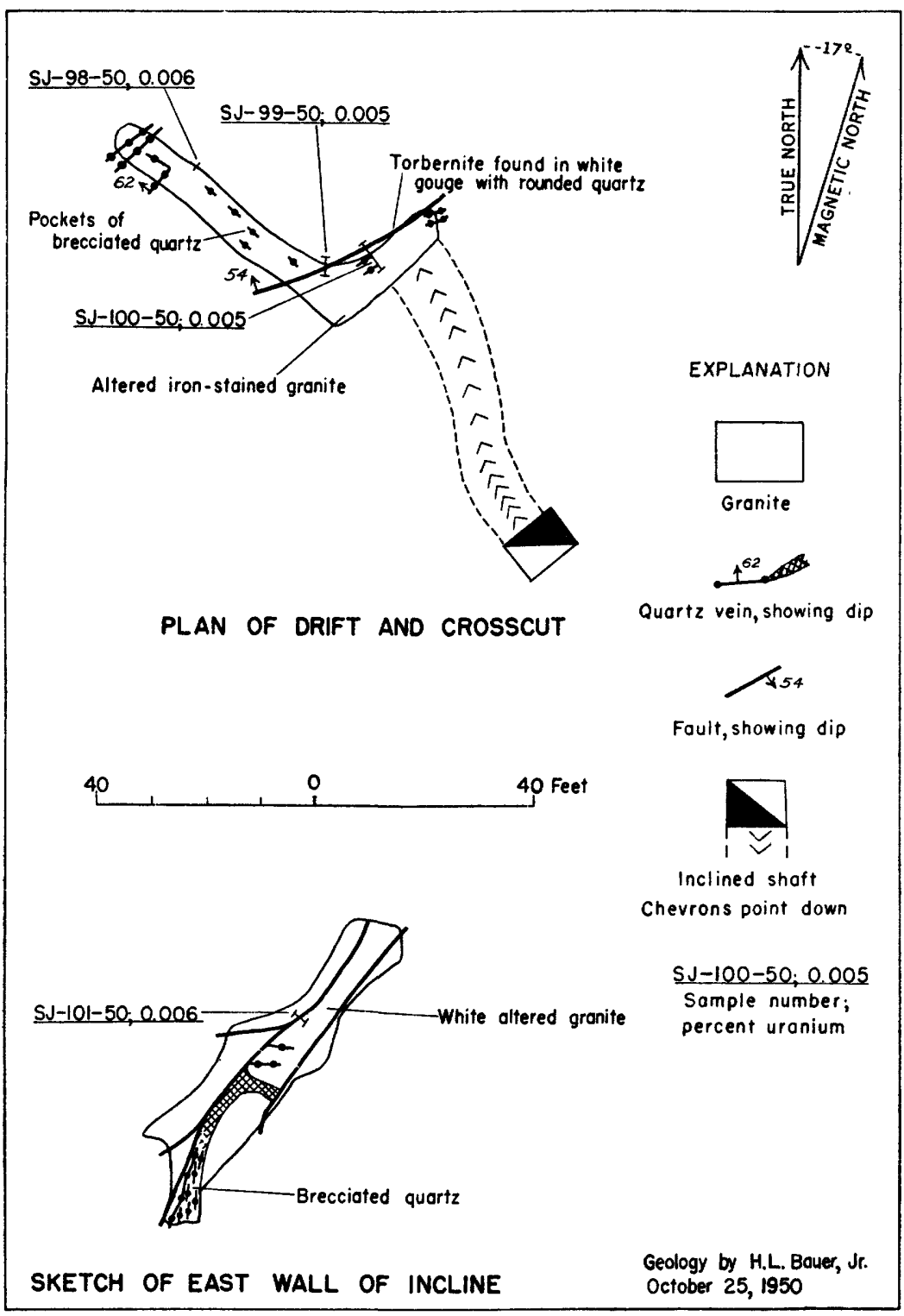

Figura 16.-Plan and sketch of east wall of the new shaft, Silver Pick property.

The shear zone contains gouge and scattered blebs of quartz. The granite on both sides of the shear zone has been altered and silicified. Scattered small nodules of quartz containing galena, chalcocite, and reported silver minerals are in the altered zone. Locally the gouge contains a platy light-green mineral that fluoresces under ultraviolet light and is tentatively identified as torbernite.

Radiometric readings ranged from 5 to 15 divisions on the 0.2 scale 
of a Geiger counter. A few pieces of high-grade ore from the dump gave readings up to 5 divisions on the 2.0 scale. Three channel samples were cut in the tumel at the foot of the new shaft, one in the new shaft (fig. 16), and one in the short adit off the open-cut. The results of analysis are given in the following table:

Analyses of samples from Silver Pick property

\begin{tabular}{l|c|r|r|r}
\hline Sample & Location & Material & $\begin{array}{c}\text { Equiva- } \\
\text { lent } \\
\text { uranium } \\
\text { (percent) }\end{array}$ & Uranium \\
(percent)
\end{tabular}

\section{GRANT VIEW HOT SPRIŃG}

The Grant .View hot spring is about 23/4 miles south of an abandoned silver mill (see road log) on the East Walker River. The spring is in a big bend of the river valley, about $300 \mathrm{ft}$ east of the river, in sec. 8, T. 7 N., R. 27 E. The nearest road ends $23 / 4$ miles down the river at the old mill.

The hot spring is within the Grant View No. 1 claim, located in 1949 by Warren Loose, O. A. Kerlee, J. R. Ford, and L. O. Kerlee. No development work has been done.

At its source the spring water is estimated to have a temperature of about $110 \mathrm{~F}$. When a Geiger counter probe was held directly over the water, the counter registered from 8 to 20 divisions on the 0.2 scale and averaged about 10 divisions, compared with an average reading elsewhere of about 4 divisions.

A sample of the water and one of the sand through which the water seeped at the head of the spring were collected. When analysed several weeks later, the water sample contained $0.02 \mathrm{ppm}$ of uranium, and the sand contained 0.008 percent equivalent uranium and 0.002 percent uranium. Because the quantity of uranium in the water is not sufficient to give abnormal readings on a Geiger counter, it is concluded that the radioactivity of the spring is due to radon, which has a short radioactive life.

\section{BOERLIN RANCH RADIOACTIVE AREA}

The Boerlin ranch radioactive area is on a ridge top about $500 \mathrm{ft}$ above and a quarter of a mile west of the East Walker River. The area is about 2 miles down river (north) from the old Boerlin ranch, now part of the East Walker ranch, and is in sec. 18, T. 7 N., R. 27 E. The vearest road ends at the Boerlin ranch.

No claims have been located, and no work has been done. The radio- 
activity was discovered by Warren Loose, who guided the writers to the area.

The country rock is coarse-grained porphyritic granite. A zone of altered iron-stained and silicified granite trends N. $65^{\circ} \mathrm{E}$., and it is sporadically exposed along the top of the ridge in an area about $80 \mathrm{ft}$ long and as much as $25 \mathrm{ft}$ wide. At one spot several small quartz veins, 1 in. to $8 \mathrm{in}$. thick, were seen. Radiometric readings ranged from 4 divisions on the 0.2 scale to 4 divisions on the 2.0 scale of a Geiger counter, compared to readings elsewhere averaging about 4 divisions on the 0.2 scale. The higher readings were noted in only one area about $1 \mathrm{ft}$ across, where readings ranged from 15 divisions on the 0.2 scale to 4 divisions on the 2.0 scale. Two feet away from this area, the radioactivity reading dropped to 6 divisions on the 0.2 scale. The average reading for the whole altered zone was about 7 divisions on the 0.2 scale. One channel sample (BS-5-50) was taken from argillized granite at a place where the counter registered 7 to 15 divisions on the 0.2 scale. The sample contains 0.010 percent equivalent uranium and 0.009 percent uranium. 


\section{INDEX}

Analyses of samples, Far West Willys

$$
\text { group }
$$

Lewis coal mine

Old Washington claim

Silver Pick property

West Willys claim

West Willys No. 7

Aplite dikes

Far West Willys group

Northwest Willys group

Boerlin ranch radioactive area_._- 31, 41-42 porphyritic granite quartz veins

Coal-bearing shales, Tertiary

Coal beds, Tertiary

Dikes, aplite

Far West Willys group__._._-

Northwest Willys group._...

Far West Willys group $31,33-35$; pl. 4 analyses of samples perthite-quartz pegmatites porphyritic granite silver $33,34,35$ quartz veins $33,34,35$ dimensions 32 ; pls. 4-6

Geology of area

Granite, porphyritic

Boerlin ranch radioactive area_-

Far West Willys group

Northwest Willys group_._-_-

West Willys group

Grant View hot spring radioactivity _._._._____ $32,33,41$ radon _..._. 32,41

Kasolite West Willys group____-_-_-_-_ 37

Lewis coal mine analyses of samples

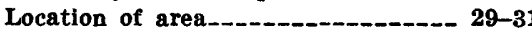

Northwest Willys group 31, 35-36 porphyritic granite quartz veins 35,36

old Washington mine, or claim_- 36, 38-39 analysis of samples silver

old Washington mining district Far West Willys group West Willys group 37,39
Page

Quartz veins, Boerlin ranch radioactive area__._._._. 42

Far West Willys group___._ $33,34,35$ dimensions___._. 34

Northwest Willys group_______ 35,36

radioactivity _._. 33

Silver Pick property _._._._. 40

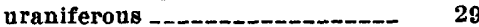

West Willys group_..... $36,37,38,39$

Radioactive material__________-_ 32-33

Radioactivity, Grant $v$ iew hot spring _._______ $32,33,41$

quartz veins_._._._. 33

Silver Pick property__.______- 33

Radiometric measurements_______ 31-32

Radon, Grant View hot spring _._._. 32, 41

Road log-_._. 31

Silver -

Far West Willys group_.____ 33, 34, 35

old Washington mine-______ 38

Silver Pick property___._._._. 39,40

West Willys No. 7 claim _..._. 38

Silver Pick property $\ldots \ldots \ldots$ 31, 32, 39-41

analyses of samples___________ 41

quartz veins_._._._-_._-_._. 40

radioactivity _._._._. 33

silver -_.

torbernite_._._._._._._._._. 32,40

uranium minerals, discovery_-_- 39

Tertiary, coal-bearing shales_______ $\quad 32$ coal beds . 32

Torbernite, Silver Pick property West Willys group_________ 32,39

Uraniferous deposits_________-_ 29

Uranium minerals _._._. 32 discovery, Silver Pick property _- 39 occurrence -

West Willys group____ $31,36-39$; pls. 5-7 kasolite_._._. 37 pitchblende________________ 37,39 porphyritic granite________ $36, \mathbf{3 7}, 38$ quartz veins__________ $36,37,38,39$ torbernite_______________ 32,39 West Willys claim____ $31,36-37$; pl. 5 analyses of samples

West Willys No. 2 claim___._ 36, 37-38 West Willys No. 4 claim__._____ 36,38 West Willys No. 7 claim__._- 32, 36, $38-39$; pls. 6,7 analyses of samples_______- $\quad 39$ silver _-_-_-_- 38 
